\title{
Evaluation of the Effectiveness of Dialectical Behavior Therapy based on Emotion Regulation Skills Training on Impulsivity and Cognitive Emotion Regulation in Type 1 Bipolar Patients \\ Mahmoud Farvarshi', Marziyeh Alivandi Vafa ${ }^{2}$, Ali Fakhari ${ }^{3}$, Masoumeh Azmoudeh ${ }^{4}$ \\ 1. Ph.D. Student, Department of Psychology, Faculty Of Humanistic \& Educational Sciences Tabriz Branch, Islamic Azad University, Tabriz, ran. ORCID: 0000-0003-0094-7483. \\ 2. Assistant Professor, Department of Psychology, Faculty Of Humanistic \& Educational sciences Tabriz Branch, Islamic Azad University, Tabriz, Iran ,(Corresponding Authol) ,Tel: +98 9148453325, Email: m.alivand@iaut.ac.ir ORCID: 0000- 0002-1197-9598. \\ 3. Professor, Razi Hospital, Tabriz University of Medical Sciences, Tabriz, Iran. ORCID:0000-0002-3731-7146. \\ 4. Assistant Professor, Department of Psychology, Faculty of Humanistic \& Educational Sciences, Tabriz Branch, Islamic Azad University, Tabriz, Iran .ORCID: 0000-0003-1534-9814.
}

\begin{abstract}
Background and Aim: Bipolar disorder type 1 is a chronic, debilitating and recurrent disorder that is defined by specific periods of mania and this disorder causes a great deal of intrapersonal and interpersonal disorder. Overall, the present study aimed to investigate the effectiveness of dialectical behavior therapy based on emotion regulation skills training on impulsivity and how to cognitively regulate emotion in type 1 bipolar patients.

Materials and Methods: The present study was based on quasi-experimental studies with pretest-post-test design with a control group. The statistical population of this study consisted of all male patients admitted to Razi Hospital in Tabriz in 2018. Purposeful sampling method was used to obtain a statistical sample (30 people); Also, to reduce the difference between the groups, the sample was randomly divided into experimental and control groups. In order to obtain the research data, Barthes Impulsivity Questionnaire and Gabreski_Emotion Cognitive Emotion Regulation Strategies were used. To analyze the obtained data, multivariate analysis of covariance with SPSS- 24 statistical software was used.

Results: The results of statistical studies showed that dialectical behavior therapy had a significant effect $(\mathrm{p}<0.05)$ on improving impulsivity and cognitive emotion regulation strategies (except blaming others and refocusing on planning, accepting and adopting other perspectives) of bipolar patients.

Conclusion: The findings indicated that dialectical behavior therapy based on emotion regulation skills training can be used to reduce impulsivity and cognitive emotion regulation in patients with type 1 bipolar disorder in combination with medication.
\end{abstract}

Keywords: Bipolar Disorder Type I, Impulsivity, Cognitive Emotion Regulation, Dialectical Behavioral Therapy

Received: June 4, 2019

Accepted: Aug 30, 2019

How to cite the article: Mahmoud Farvarshi, Marziyeh Alivandi Vafa, Ali Fakhari, Masoumeh Azmoudeh. Evaluation of the Effectiveness of Dialectical Behavior Therapy based on Emotion Regulation Skills Training on Impulsivity and Cognitive Emotion Regulation in Type 1 Bipolar Patients.व́Q́SJKU 2021:26(2):79-92.

Copyright (C) 2018 the Author (s). Published by Kurdistan University of Medical Sciences. This is an open access article distributed under the terms of the Creative Commons Attribution-Non Commercial License 4.0 (CCBYNC), where it is permissible to download, share, remix, transform, and buildup the work provided it is properly cited. The work cannot be used commercially without permission from the journal 


\section{بررسى اثربخشى رفتار درمانى ديالكتيكى مبتنى بر آموزش مهارتهاى تنظيم هيجانى بر تكانشكرى و تنظيم

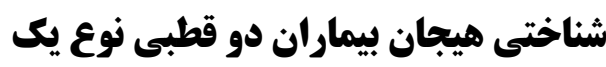 \\ محمود فرورشى'، مرضيه عليوندى وفا'، على فخارى"، معصومه آزمودهء}

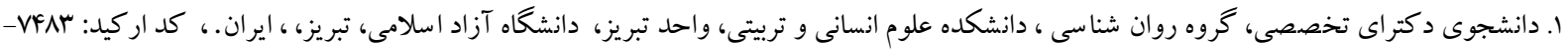

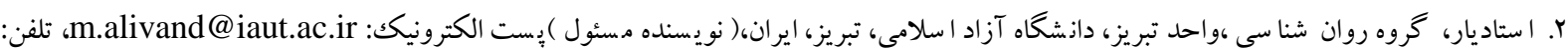

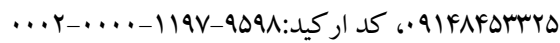
r.

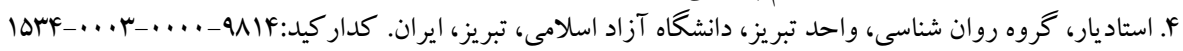

زمينه و هدف: اختلال دوقطبى نوع يك،، اختلالى مزمن، ناتوان ساز و عودكننده است كه با دورههاى مانيا تعريف شده است و اين اختلال باعث بســيارى از اختلالات درون فردى و بين فردى مى شــود. در كل، تحقيق حاضـــر بر آن بود تا ميزان اثربخشـى رفتاردر مانى ديالكتيكى مبتنى بر آموزش مهارت هاى تنظيم هيجان را بر تكانش گرى و جِكونكى تنظيم شــناختى هيجان بيماران دوقطبى نوع يكك بررسى نمايد. مواد و روش ها: تحقيق حاضر از لحاظ روش تحقيق بر اساس بزٔوهش هاى نيمه تجربى با طرح ييش آزمون - يس آزمون با گروه

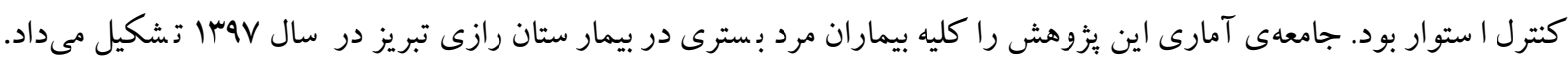
براى به دسـت آوردن نمونهى آمارى (• • نفر)، از روش نمونه گيرى هدفمند اسـتفاده گرديد؛ همجينين براى كاهش ميزان تفاوت گروهها، نمونه به روش جايخزينى تصادفى در دو گروه آزمايش و گگ اه قرار داده شد. به منظور به دست آوردن دادههاى تحقيق، از برسشنامههاى تكانشخرى بارت و ر اهبردهاى تنظيم شناختى هيجان گارنفسكى استفاده شد. براى تجزيه و تحليل داده هاى حاصله، از روش آمارى تحليل كوواريانس جند متغيره با نرم افزار آمارى SPSS- YF استفاده شد.

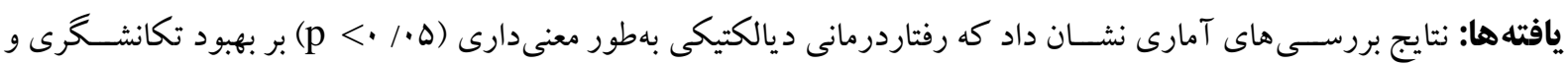
راهبردهاى تنظيم شــناختى هيـجان (بهجز ملامت ديخران و تمركز مجدد به بر نامهريزى، يذيرش و اتخاذ ديد كاه ديخر ) بيماران دوقطبى تأثير داشته است. نتيجه كيرى: يافته ها حاكى از آن بود كه مى توان از رفتاردر مانى ديالكتيكى مبتنى بر آموزش مهارت هاى تنظيم هيجان براى كاهش تكانشخرى و تنظيم شناختى هيجان مبتلايان به اختلال دوقطبى نوع يكك همر اه با دارودرمانى استفاده نمود. كلمات كليدى: اختلال دوقطبى نوع يكك، تكانشكرى، تنظيم شناختى هيجان، رفتار درمانى ديالكتيكى

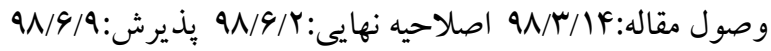


شــه اسـت. در اصـل، اين نوع رفتار بدون انديشسيدن به اين

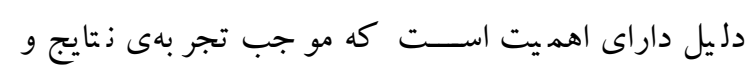

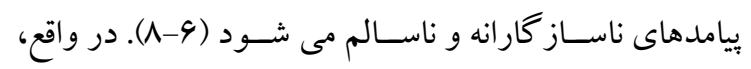

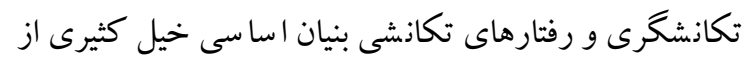
اختلالات روان شـناختى بوده و در اختلال دو قطبى نيز از

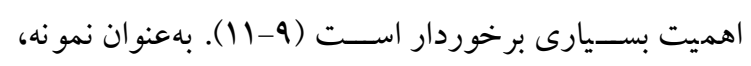

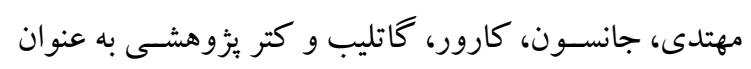
رويكرد مقطعى به تكانشـحرى در بي ماران داراى اختلال

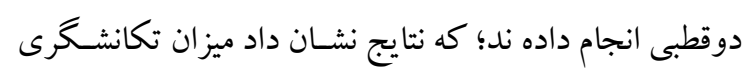

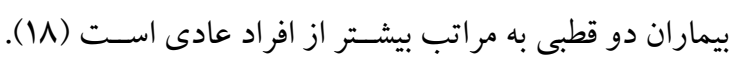

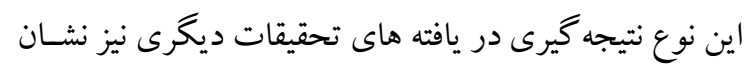

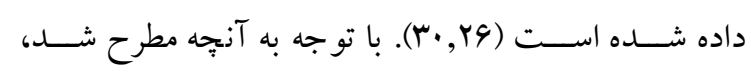

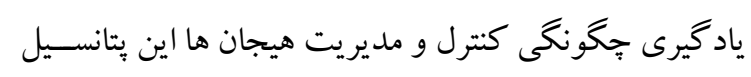

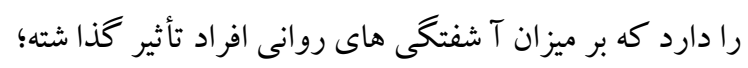

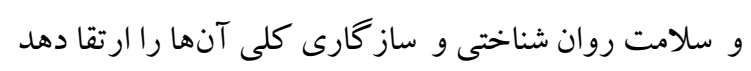

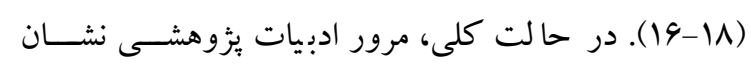

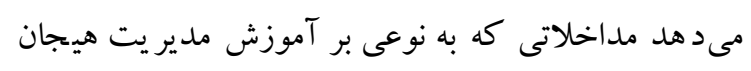

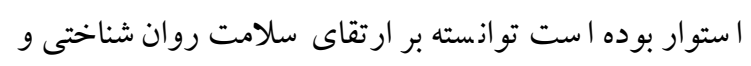
كاهش آشـفتخى هاى روانى بيماران دوقطبى مورد مـطالعه أنه

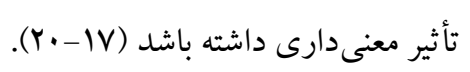

از طرفى، يرواضح است كه ندا شتن آكاهى از زبان هيجانها

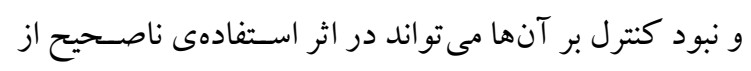

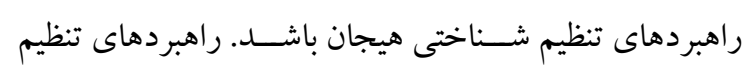

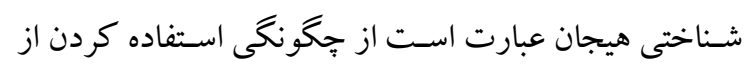

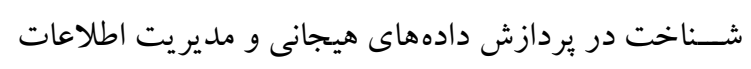

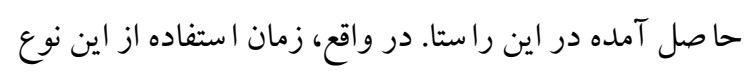
راهبردها آن هنكامى اسـت كه فرد در حال تجربهى فشــار روانى باشد. بررسى هاى تجربى رابطهى بين راهبردهاى تنظيم

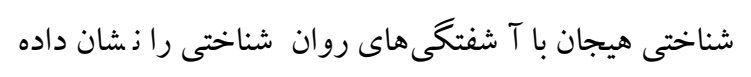

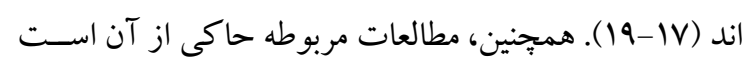

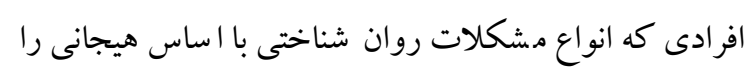

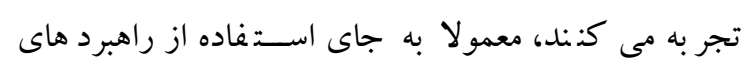

\section{مقدمه}

جندى اســت كه متخصــصــــان امر، اختلال دو قطبى را با

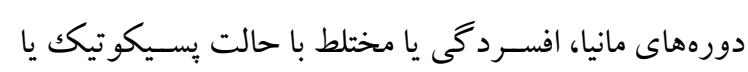

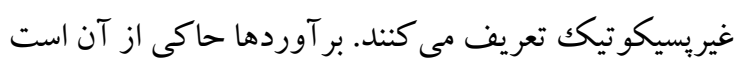

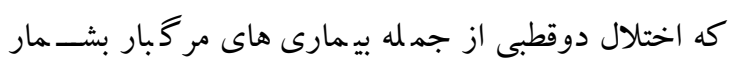
مى رود؛ جر اكه نه تنها اين بيمارى دومين عامل ناتوان سـاز دهاز

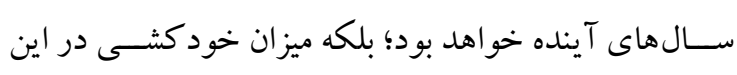

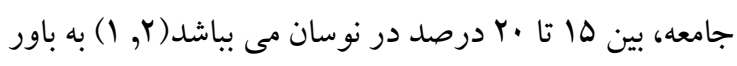
متخصصصان اين حوزه، دامنه ى شيوع اختلال دو قطبى جنان

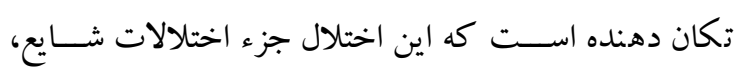
سخت و ناتوان ساز روان بز شكى بشمار مى آيد.

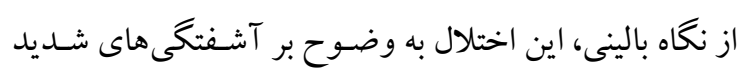

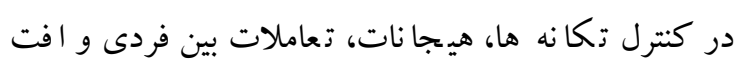

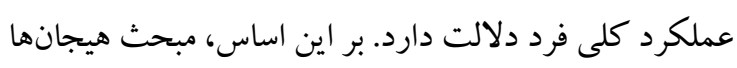

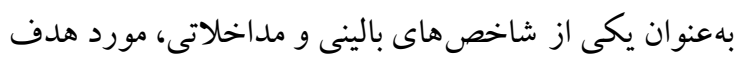

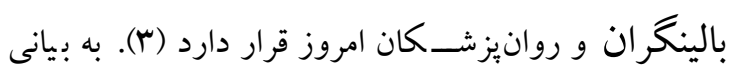
ديخر، اخرجهه اسـتفاده از دارو در درمان اين اختلال بســيار

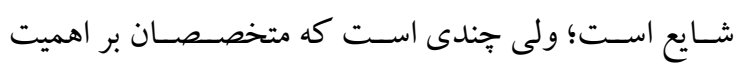

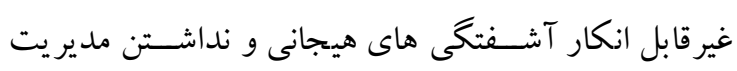
هيجان در كيفى سازى درمان و جلو گيرى از عود تأكيد وافر دارند. بررسى نتايج درمان هاى هيجان مدار نشان مى دهد كه دهان دخيل دان ستن فاكتور هيجان بهعنوان وزنهى درمانى مى تواند

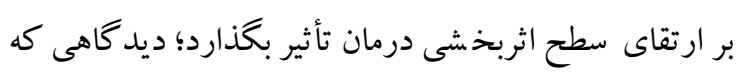

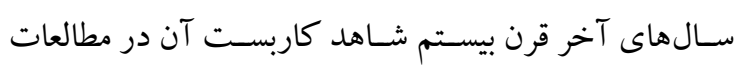

$$
\text { بالينى تجربى بود (ه, (F). }
$$

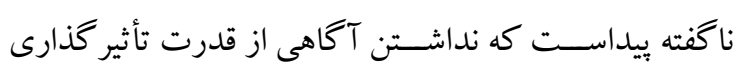

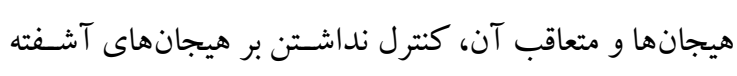

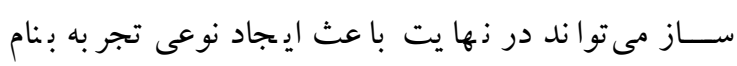
تكانشخرى شود. در حقيقت، تكانشخرى، رفتارى مهار نشده

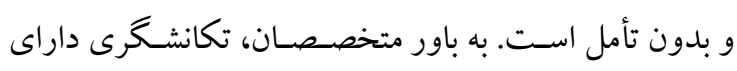

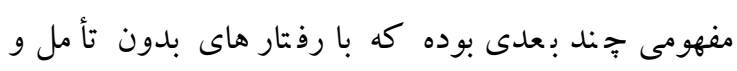

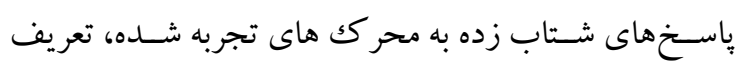


كه اسا ساً داراى جارجوبى روانى - آموز شى بوده و بر فلسفه

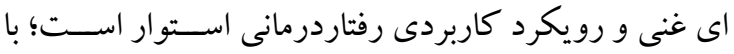
تكيه بر قدرت هيجان ها، بر اين موضــوع تأكيد دارد كه رونه صـرف اسـتفاده از ويزيتهاى كو تاه مدت غير بالينى دارو مدار نمى تواند به شكل بنيادين بر علائم اختلال دوقطبى مؤثر

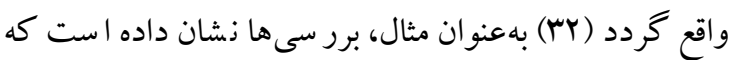
داروهاى تثبيت كنندهى خلق از قدرت اثربخشى بالايى براى

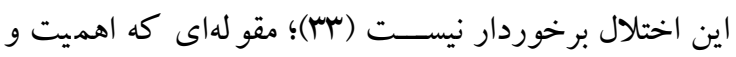
ضرورت انجام تحقيقات روان درمانى را بيش از بيش نمايان

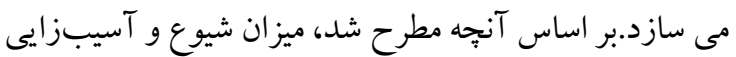
اختلال دوقطبى بسيار هشدار دهنده است؛ از طرفى، با توجه

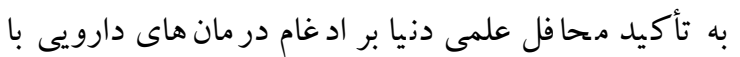

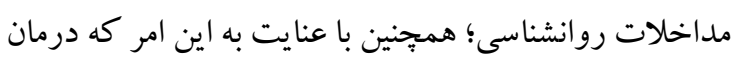

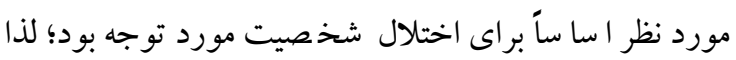
انجام يزوهش هايى با انواع اختلالهاى روانى شديد مى تواند

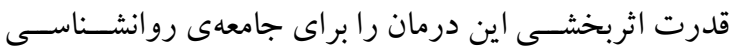

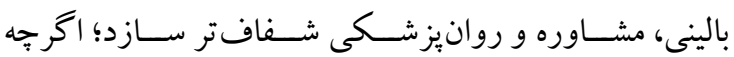

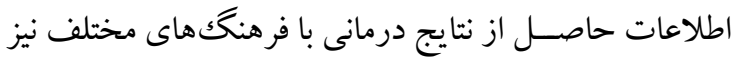

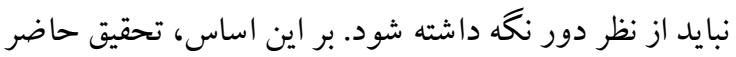

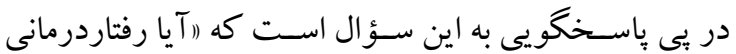

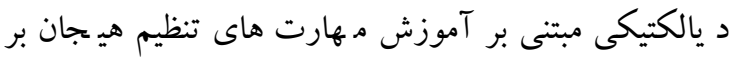
كاهش تكانشــرى و بهبود تنظيم شــناختى هيجان بيماران دوقطبى نوع يك تأثير دارد؟)|

\section{مواد و روش ها} طرح تحقيق حاضر بر اساس طرح هاى شبه آزمايشى از نوع

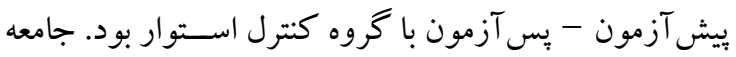

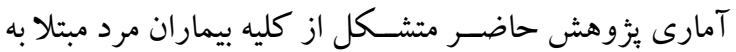

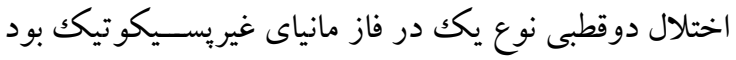

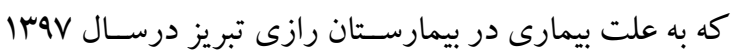
بسترى بودند. با توجه به اين امر كه مراحل تشـخيصسى اين

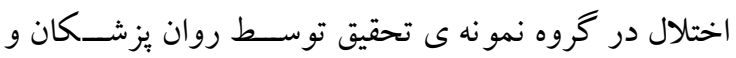

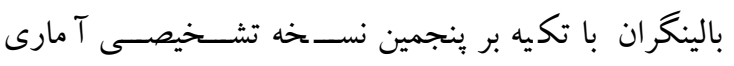

ســاز گارا نه (مانند بِذيرش، ارز يابى مجدد مثبت)، از راهبردهاى مقابله اى ناسـاز گار (مانند فاجعه سـازى، ملامت ديخران) اسـتفاده مى نمايند؛ روش هايى كه مى تواند در

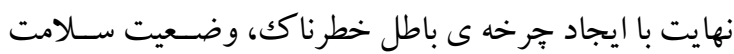

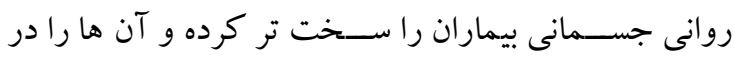

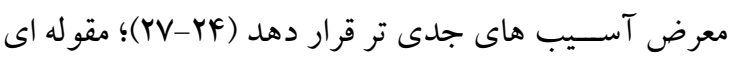
كه در اختلال دو قطبى نوع يكك داراى ادبيات تجربى قوى درى دهر نمى باشد. با توجه به جنس آثــنتخى هاى بيماران دو قطبى و ناتوانى

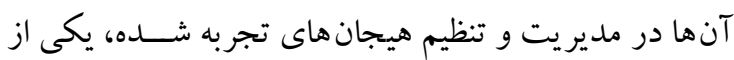

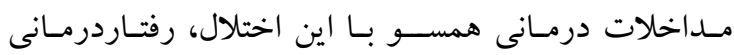

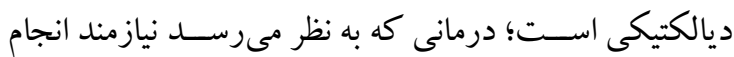

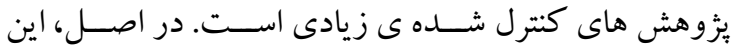
درمان كه توسـط ابداع كننده آن براى اختلال شــخصـيت مرزى با ســاختارى تعريف شــده ســاخته شـــده بود؛ بعدها كارايى خودش رادر ساير اختلالات شخصيت و اختلالات

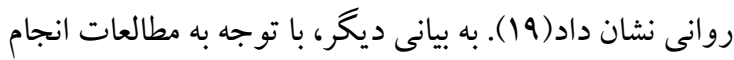

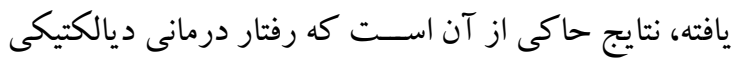

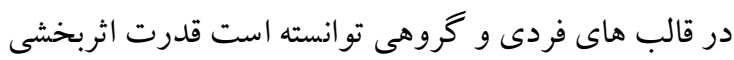
خود را در در مان و كاهش علائم بسـيارى از اختلالات شخصيت و اختلالات روانى مانند اختلال دو قطبى نشان دهد

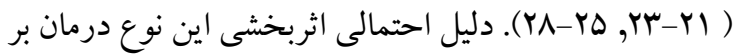

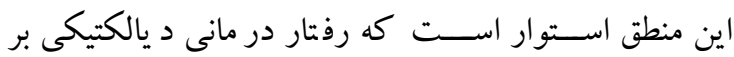
متغيرهايى حساس است كه مشكل اساسى اين بيماران است. در حقيقت، در بطن اين درمان، آموزش ذهن آكاهى، تحمل يريشـانى (مهارت هاى بذيرش) و روابط بين فردى و تنظيم هيجان (مهارتهاى تغيير) مورد توجه قرار دارد؛ كه البته دو

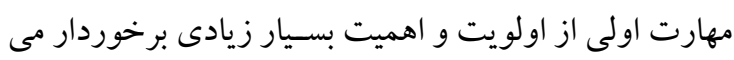

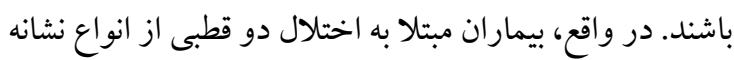

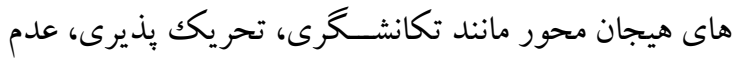

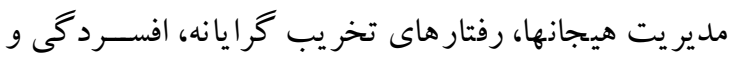

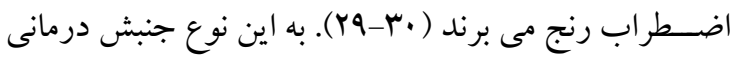




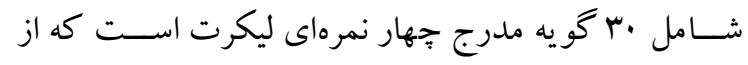

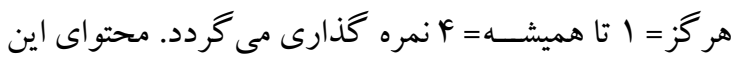

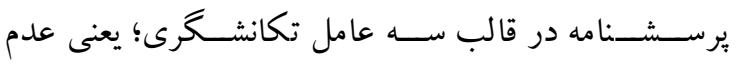

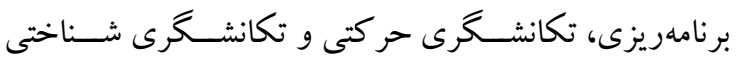

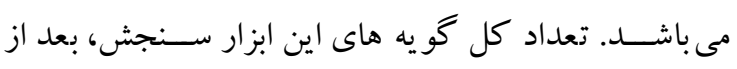

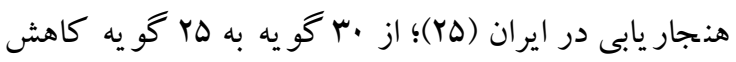

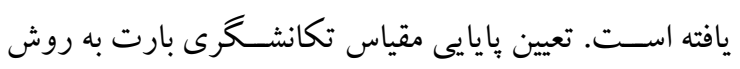

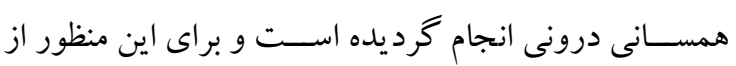

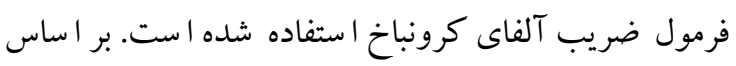

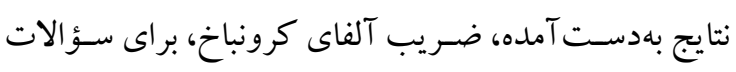

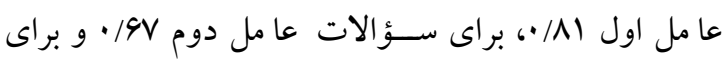

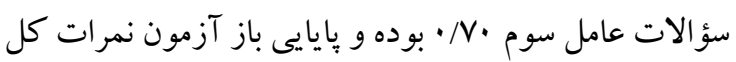

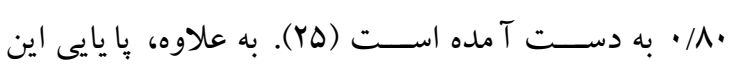

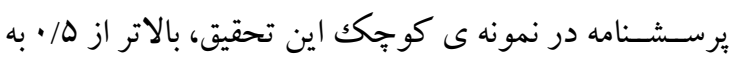

دست آمد (ri).

بر سشنامه تنظيم شناختى هيجان كارنفسكى: اين بر سشنامه خود سنجى وب سؤ ال دارد كه توسط كارنفسكى و همكاران

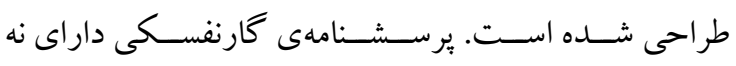

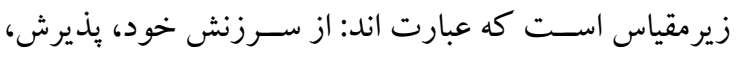
نشخوارذهنى، توجه مجدد مثبت، توجه مجدد به برنامهريزى،

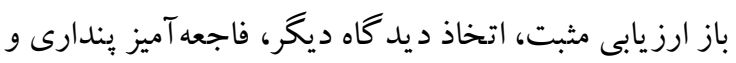

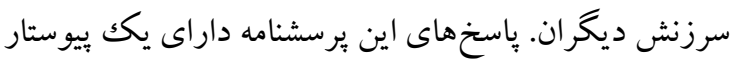

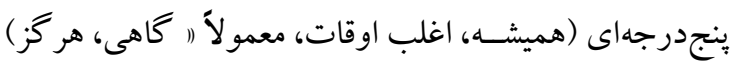

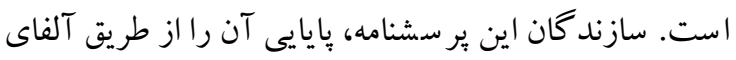

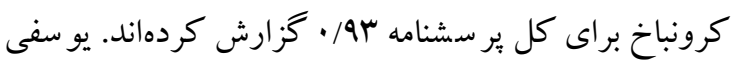

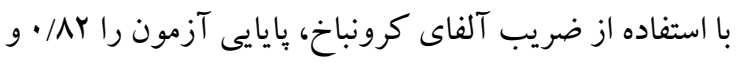

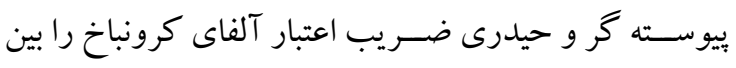
191/ • تا هـ/ • گزارش كرده اند (r)

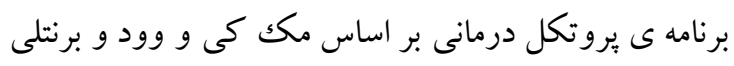

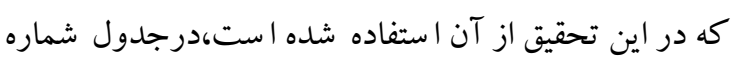

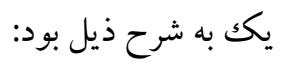

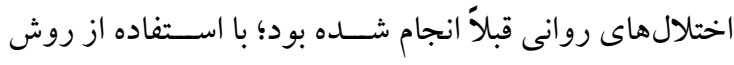

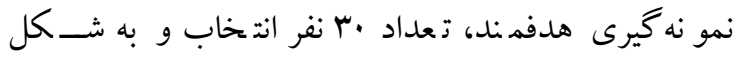
جايخزينى تصادفى در گروههاى آزمايش و كنترل قرار داده

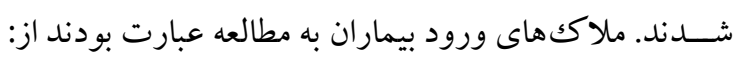

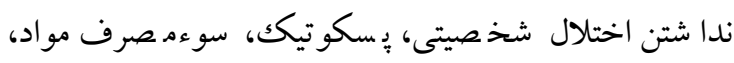
افكار جدى خود كشـى و بسـترى بيش از ســه بار، داشــتن

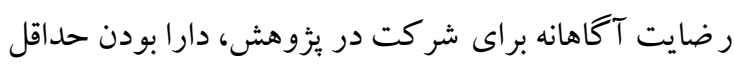

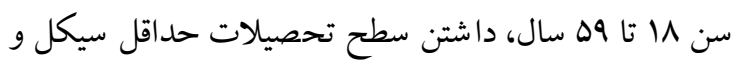

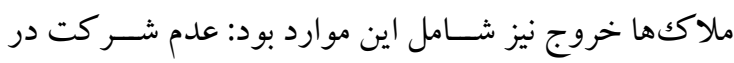

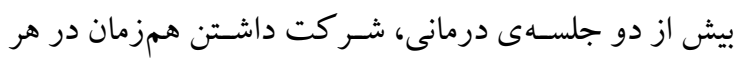

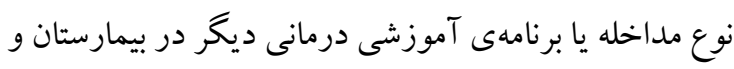

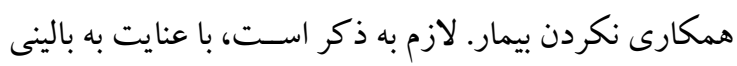

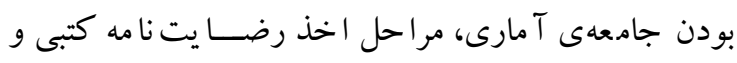

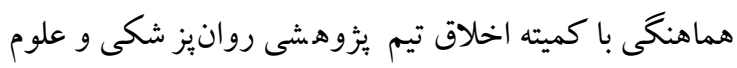

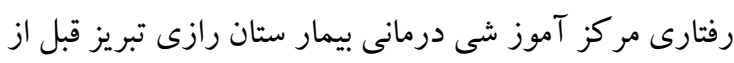

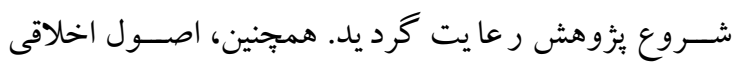
انجمن روانشنا سى آمريكا (احترام به اصل رازدارى بيمار ان،

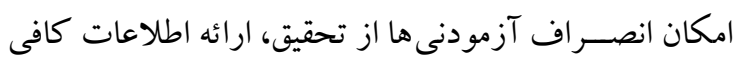

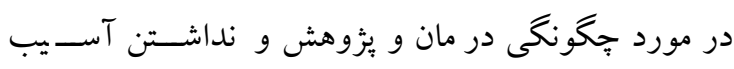
جسمانى) مورد نظر محقان قرار داده شد. مسير انجام مداخله

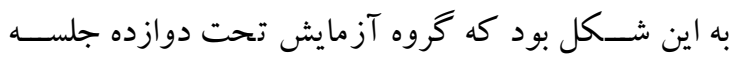
هفتخى رفتاردرمانى ديالكتيكى (با تكيه بر مهارتهاى تنائ تنظيم

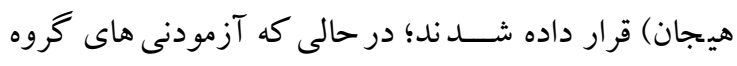

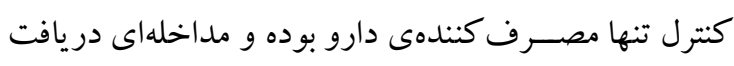

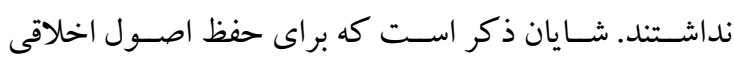
انسانى، مقرر شد بعد از اتمام دورهى درمانى گروه آزمايش،

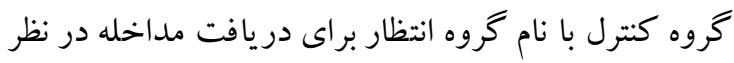

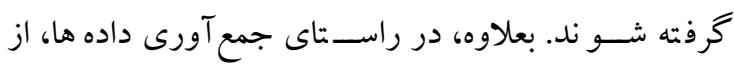
ير بشنامه هاى ذيل استفاده شد:

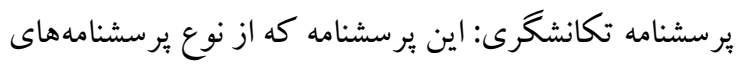

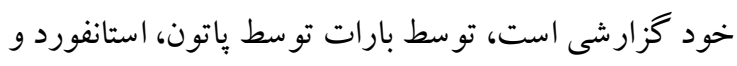
بارت (1990) معرفى شـده اسـت. مقياس تكانشـخرى بارات

جدول ا. محتواى ثروتكل رفتاردرمانى ديالكتيكى(آموزش مهارتهاى تنظيم شناختى هيجان) 


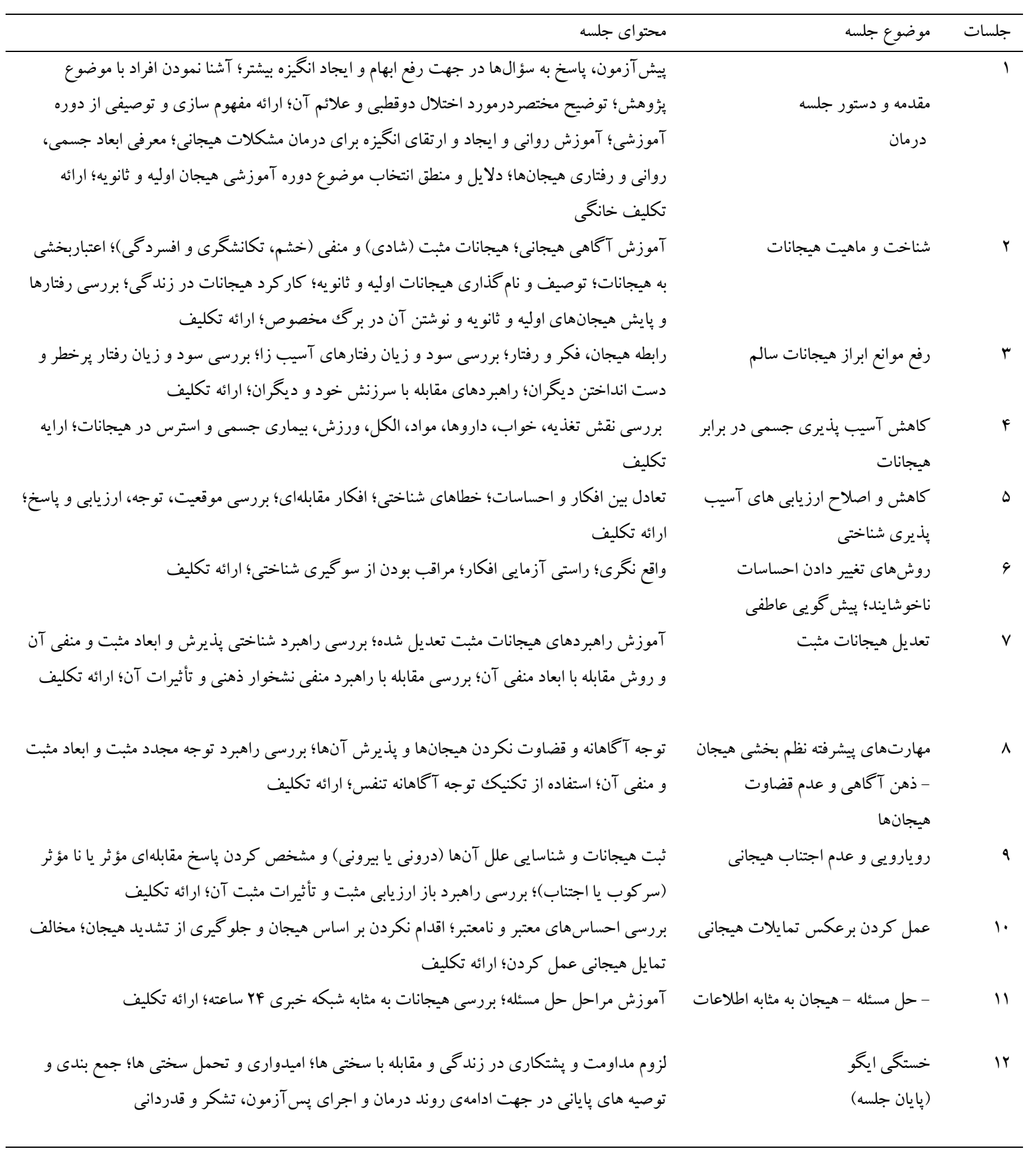

\section{يافته ها}

دانشـاه داشـتند؛ اگر جه بيشـترين آزمودنى ها، يعنى \1 نفر

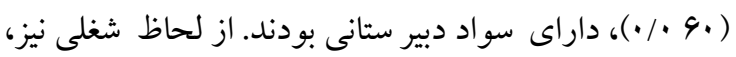
كل آزمودنى هاى مورد مطالعه شــغل غير دولتى داشــتند. بعلاوه، سـابقه بسـترى بيماران هر دو گروه، بين ا تا سـه بار
با توجه به نتايج حاصـل از تجزيه و تحليل آمار توصـيفى،

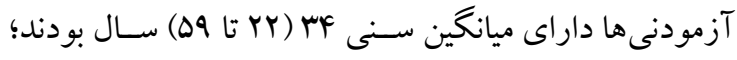
كه F| نفر آن ها مجرد و اب نفرشــان متأهل بود. از لحاظ سواد نيز، گروه مورد مطالعه داراى تحصيلاتى بين سيكل تا 
در مرحله مانياى غير بسـيكوتيكك تأثير دارد)؛ مورد آزمون

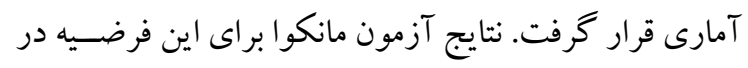
ذيل ارائه شده است.
بود. در جريـان آزمون فرضـيـه هـا، بعـــ از اطمينـان از

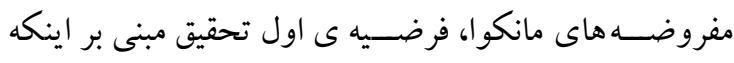

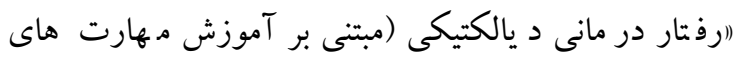

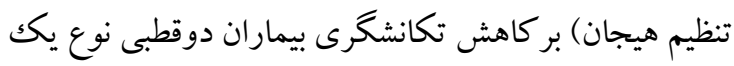

جدول r. آزمون حند متغيرى تفاوت ميانكين ها بر اساس رفتار درمانى ديالكتيكى در بين بيماران دو كروه (تكانشكرى)

\begin{tabular}{|c|c|c|c|}
\hline مجذور اتا & سطح معنى دارى & واريانس & مقدار \\
\hline$\cdot 199$ & $/ \bullet$ & $I V / D G$ & بلداى ويلكز \\
\hline
\end{tabular}

$$
\mathrm{P}<\cdot / \cdot \Delta
$$

جلسات روان درمانى رفتاردرمانى ديالكتيكى دركروه آزمايش درحالت كلى متغيرتكانشخرى بيماران مانيكك را به ميزان 99 درصد كاهش داده است .

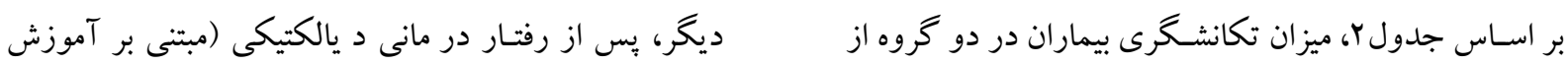

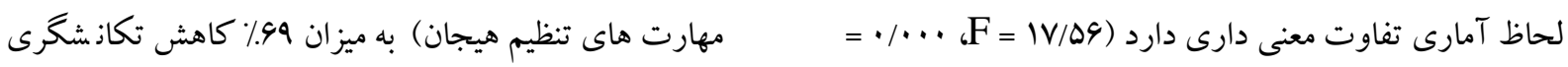

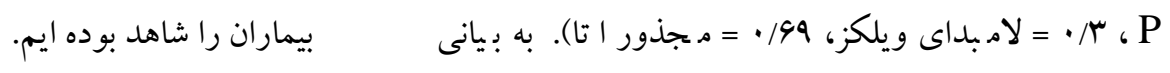

\begin{tabular}{|c|c|c|c|c|c|c|c|}
\hline مجذوراتا & دارى سطح معنى & واريانس & مجانگين & درجه & مجذموع & 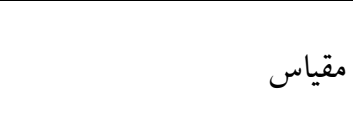 & منبع \\
\hline$\cdot / T \Lambda$ & $\cdot / \cdot f$ & 1.110 & $\mid V F / D$ & 1 & $\mid V F / D$ & تكانشخرى عدم برنامهريزى & \\
\hline$\cdot / \mu$ & $\cdot / \cdot r$ & $1 \cdot / V^{F}$ & $r \Lambda \cdot / v \Lambda$ & 1 & $\mu \wedge \cdot / v \wedge$ & تكانشخرى حر كتى & 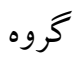 \\
\hline$\cdot / r$. & $\cdot / \cdot r$ & $11 / r$ & $G F / N F$ & 1 & $G F / V F$ & تكانشگرى شناختى & \\
\hline
\end{tabular}

جدول Г. نتايج تحليل واريانس جند متغيره براى مقايسه مولفهاى تكانشكرى بيماران دوقطبى در كروههاى آزمايش و كنترل

بيماران مانيك گروه آزمايش بعد از انجام روان درمانى ديالكتيكى، تكانشخرى هاى حر كتى ، شناختى و شناختى كاهش يافته است.

وابسته به صورت جدا كانه در نظر گرفته شد، مشاهده گر ديد

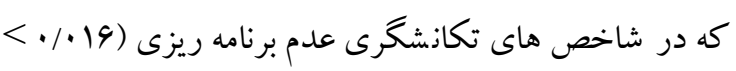

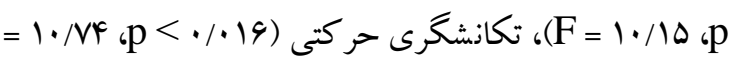
F و تكانشـخرى شـناختى (F) معنى دار وجود دارد.
پِ آز ازبات اثربخشـى رفتاردر مانى د يالكتيكى (مبتنى بر

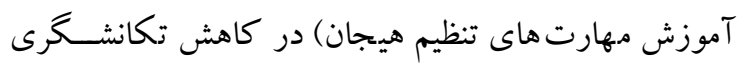

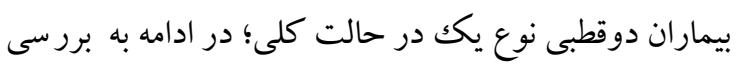

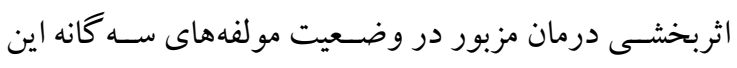

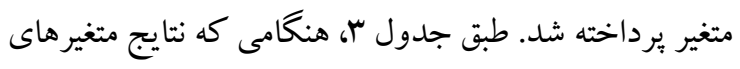

جدول ع. ميانكين نمرات مولفهاى تكانشكرى بيماران براساس شر كت يا عدم شر كت در رفتار درمانى ديالكتيكى 


\begin{tabular}{|c|c|c|}
\hline ميانكين & كروه & مؤلفه ها \\
\hline Ir/AN & آزمايش & \multirow{2}{*}{ تكانشگرى عدم برنامه } \\
\hline $19 / V 1$ & كنترل & \\
\hline$T I / T G$ & آزمايش & \multirow{2}{*}{ تكانشَرى حركتى } \\
\hline$r q / \wedge V$ & كنترل & \\
\hline GIAT & آزمايش & \multirow{2}{*}{ تكانشخرى شناختى } \\
\hline $1 \cdot / r V$ & كنترل & \\
\hline $41 / 9 V$ & آزمايش & \multirow{2}{*}{ تكانشخرى } \\
\hline $09 / 94$ & كنترل & \\
\hline
\end{tabular}

كاهش ميانگين مولفه هاى تكانشخرى و خود كل تكانشخرى را در گروه آزمايش بعد از انجام جلسات رفتار درمانى ديالكتيكى نشان مى دهد.

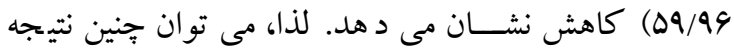
يافته هاى جدول F نشـــان مى دهد كه ميانكين نمره كر فت كه شــر كت در دورهى مداخله ایى رفتتار در مانى

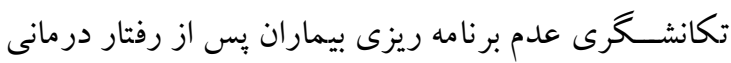
ديالكتيكى توانسته است در كاهش ميزان تكانشگُرى بيماران

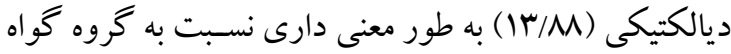
و مؤلفهاى آن تأثير بسزايى داشته است. (با ميانخين | (9/V) كاهش يافته اســ؛ همجنين، ميان نمره در فرضسيـه دوم تحقيق نيز مبنى بر اينكـه ارفتـاردرمـانى

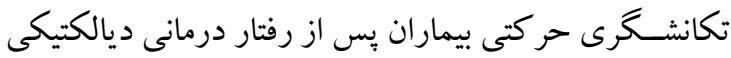
د يالكتيكى (مبتى بر آموزش مهارت هاى تنظيم هيجان) بر

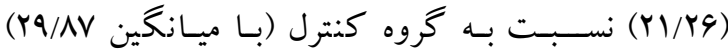
تنظيم هيجانى شــناختى بيماران دوقطبى نوع يكك در مرحله كاهشيافته است؛ بعلاوه، نمره ميانگين تكانشكرى شناختى

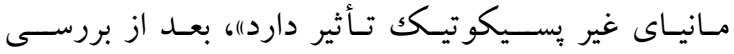
بيماران بس از رفتاردر مانى د يالكتيكى (G/AY) نسـبت به مفروضسـه هاى آ مارى مورد نظر، از تحليل وار يانس جِند

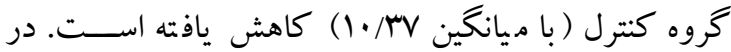
متغيرى (مانكو ا) استفاده شد. - ماك.

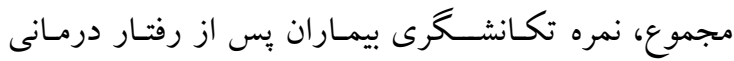
د يالكتيكى (Fl/aV) نس-بت به كروه كنترل ( با ميانگين

\begin{tabular}{|c|c|c|c|c|}
\hline \multicolumn{5}{|c|}{ در كروههاى آزمايش و كنترل (تنظيم شناختى هيجان) } \\
\hline مجذور اتا & سطح معنىدارى & واريانس & مقدار & \\
\hline . Ar &.$/ . * F$ & $\Delta / 91$ &.$/ \mathrm{V}$ & بلكز \\
\hline
\end{tabular}

$\mathrm{P}<\cdot / \cdot \Delta$

بيماران مانيك گروه آزمايش بعداز شر كت در جلسات رفتاردرمانى ديالكتيكى به ميزان r درصد تتنظيم شناختى هيجان ييدا كرده اند

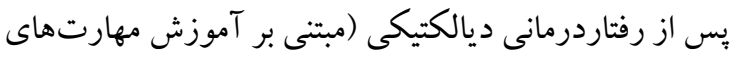
با تو جه به جدول ه، از نظر آمارى تفاوت معنى دارى بين تنظيم هيجان) توانايى تنظيم شـناختى هيجان بيماران به ميزان

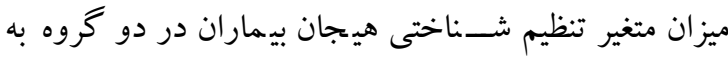

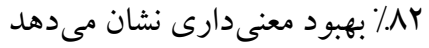
دست آمد ( ( F آب = = مجذور اتا). در اصل، بر اساس يافته هاى اين فرضيه،

\section{جدول 7 . نتايج تحليل واريانس جند متغيره در مولفهاى تنظيم شناختى هيجان بيماران دو قطبى در كروههاى آزمايش و كنترل}




\begin{tabular}{|c|c|c|c|c|c|c|}
\hline مجذور اتا & معنى دارى & واريانس & ميانگين & آزادى & مجذموع مجذورات & مقياس \\
\hline$\cdot / D F$ & $\cdot / \cdots$ & rY/Or & $19 \% / F F$ & 1 & $19 K / F F$ & ملامت خويش \\
\hline$\cdot / M F$ & $.1 \cdot 9$ & $9 / \vee 9$ & $99 / 1$ & 1 & $99 / 1$ & بذيرش \\
\hline$\cdot / F$ & $\cdot / r r$ & $\mid r / 9 r$ & $9 \Delta / V \varphi$ & 1 & $৭ \Delta / V \varphi$ & نشخوار بذيرى \\
\hline .190 & $\cdot / \cdots$ & $r \Delta / \Delta$ & $\mid r G / 1$ & 1 & $1,4 / 1$ & تمر كز مجدد مثبت \\
\hline$\cdot / 1$ & $\cdot / f F$ & $r / T \Delta$ & $1 r / 9 V$ & 1 & $14 / 9 \mathrm{~V}$ & تمركز مجدد بر برنامهريزى \\
\hline$\cdot / F V$ & $\cdot / \cdots 1$ & $\mathrm{IV} / \mathrm{IV}$ & $11 \cdot / T_{1}$ & 1 & $11 \cdot / \mu 1$ & ارزيابى مجدد مثبت \\
\hline$\cdot / \mu r$ & $\cdot / \cdot v$ & $Q / Y V$ & $9 \cdot / 91$ & 1 & $9 \cdot / 91$ & ديدگاه گيرى \\
\hline . /Or & $\cdot / \cdots$ & $r \cdot 19 Y$ & $9 \cdot 1 \wedge 9$ & 1 & $9 \cdot / 19$ & فاجعه سازى \\
\hline.$/ . r$ & $\cdot / \Delta r$ & $\cdot / A r$ & $r / l F$ & 1 & $r / l f$ & ملامت ديخران \\
\hline
\end{tabular}

رفتاردرمانى ديالكتيكى مولفه هاى تنظيم شناختى هيجان مانند تمر كزمجدد مثبت ، ارزيابى مجدد مثبت را افزايش داده وبرميانخين نمرات ملامت خويش ،

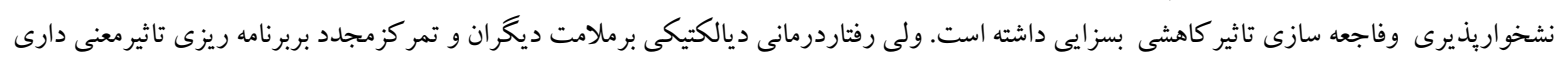
نداشته است .

درمانى ديالكتيكى (q/1)) به طور معنى دارى نسـبت به خروه كنترل (با ميانگين سم/M إ) كاهش يافته اســت. بعلاوه، نمره

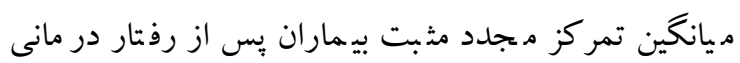

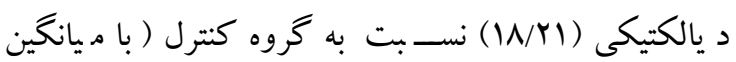
(IT/YF و همجنين نمره ميانگين تمر كز ارزيابى مجدد مثبت بيماران پِ از رفتار درمانى ديالكتيكى (IV/FA) نســبت به

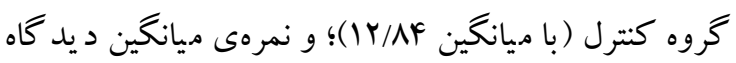

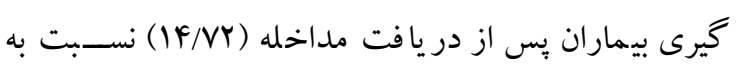

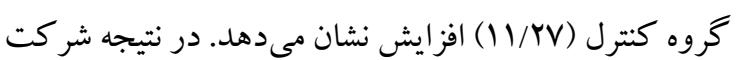
در دوره رفتاردر مانى د يالكتيكى در افزايش ميزان اين ينج شـاخص تنظيم هيجانى شـناختى بيماران تأثير بسزايى داشـته

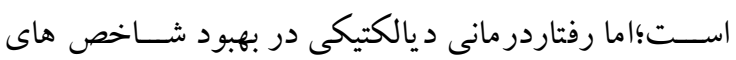
تمركز مجدد بر برنامهريزى و ملامت ديخران اثربخشى لازم رانداشته است. هنگًامى كه نتايج متغيرهاى وابســته به صـورت جداكانه در

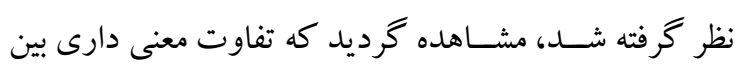

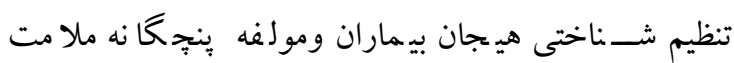
خويش، نشــخوارفكرى ، تمر كز مجدد مثبت، ارزيابى مجدد مثبت، فاجعه ســازى كروه آزمايش و كنترل وجود دارد ( • • • > $).$ جهارشـاخص يذيرش، تمر كز مجدد بر برنامه ريزى، ديدگاه

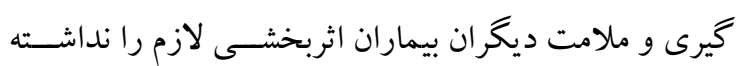

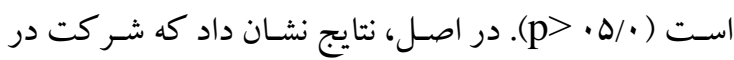
دوره ى رفتار در مانى د يالكتيكى توانسـته اســت به جز شــاخص هاى تمر كز مجدد بر برنامهريزى، ملامت ديخر ان، دورهي

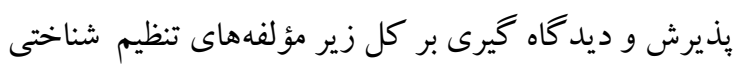

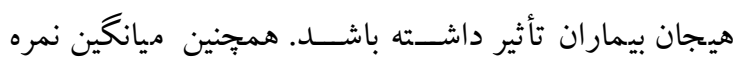

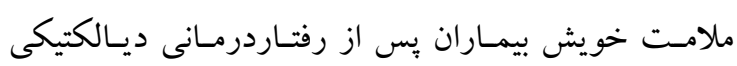

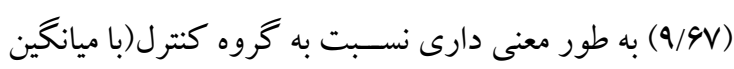

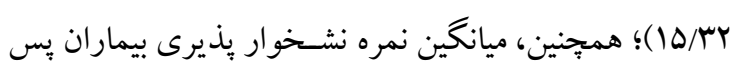

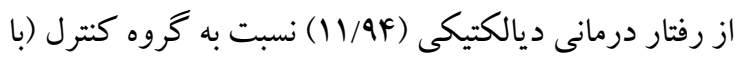
ميانگين ه/19/1)؛ و نمره فاجعه ســازى بيماران بس از رفتار 
اين تحقيق، تفـاوت معنى دارى در هر ســـه زيرمؤلفـه ى تكانشـرى (شـاختى، حر كتى و عدم برنامهريزى) مشـاهده شد؛ نتايجى كه همسو با ديخر تحقيقهاى مشابه است (Yr-

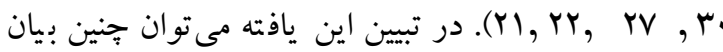
داشــت كه ياد گيرى هاى مربوط به مهارت هاى تأثير گذار فردى و بين فردى با تمركز بر هيدجان ها و دادوســتد بين هيجانها، افكار و رفتار توانسته است بر ميزان آكاهى بيماران مؤثر بوده و ميزان رفتار هاى تكانشـى آنها را كاهش دهد

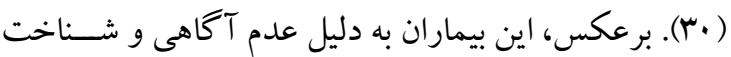
كافى از هيجانها، شناخت هاى اشتباه را درست قلمداد كرده و تكانشسى عمل مى كنند؛ كه اين خود سـبب تشـديد و بروز نشــانه هاى هاى مرضسى بيشـتر در اين بيماران مى شــود. به علاوه، مداخله آموزشـى در بر نامه هاى روزانه ى بيماران دوقطبى كـه هر آن در معرض ســو گيرى هـاى رفتـارى و متعاقب آن تكانشــرى قرار دار ند؛ قادر بوده اســت در مدير يت هيجان ها تأثير كذاشـته و رفتار هاى فردى و بين فردى آنهـا را منظمتر ســــازد. در حقيقــ، رفتـارهـاى تكانشـرى در دامنهى محدود و تعريف شـده اي اتفاق نمى افتند؛ بلكه آنها با ساير رفتارهاى آسيبزا (مانند بىبندوبارى جنسـى، نابســامانى هاى خواب، روابط بين فردى مريض) همر اهى دا شته و مششكل كنترل هيجانها را حادتر مى سازد؛ لذا، دخالت دادن فر آيند درمان در جر يان تجارب ز زندگى روزانه يكى از شــاخص هاى مهم تأثير گذارى رفتاردر مانى

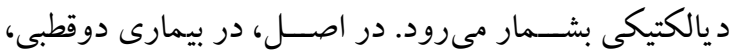
اسـاس زيربنايى اختلال را طغيانهاى هيجانى غيرقابل كنترل، بى ثباتى عاطفى، مشــكلات خلقى و نداشــتن ايدههاى ناب رفتارى براى كنترل موقعيت تشكيل داده است؛ لذا آكاهى و لئي شـناخت هيتجان ها، ياد گيرى مهارت هاى لازم براى كنترل رفتـارهـاى برخطر هيجـان محور و مــديريــت هيجـانهـاى تجربه شده، شاه كليد جر ايى مؤثر بودن اين نوع درمان است؛ جراكه باور بر اين اسـت كه نداشـتن اين نوع آكاهى عامل و باعث بسيارى از نابسامانى هاى روانشناختى است (هץ).
اين تحقيق با هدف تعيين اثربخشسى رفتاردرمانى ديالكتيكى مبتنى بر آموزش مهارت هاى تنظيم هيجان بر تكانشــرى و تنظيم شــناختى هيجان بيماران مبتلا به اختلال دو قطبى نوع يكك در فاز غيريسـيكو تيكك انجام شـده اسـت. نتايج آزمون فرضسيه ى اول نشـان داد كه رفتاردرمانى ديالكتيكى تو انسته ا ست تكانشخرى بيماران گروه آزمايش رانسبت به بيماران كروه كنترل كاهش دهد؛ اين يافته با نتايج تحقيق آقايو سفى و همكاران (MF)، فرورشى و همكاران (Yr) همسو مى باشد. در تبيين اين يافته مى توان جنين كُفت كه رفتار در مانى ديالكتيكى بر گرفته از فلسـفهى هـلى بر اصسولى تكيه دارد كه در بيى راهاندازى بتانســيل هاى فردى در جهت ارتقاى ســح كيفى ديالكتيكك فردى و بين فردى اسـت. همجِنين، هدف اساسى رفتاردرمانى ديالكتيكى همانطور كه از نامش بيداســت، در حوزهى ياددهى و ياد گيرى قرار دارد. به بيانى ديخر، به كار گيرى و تعميم مهارت هاى انطباقى خاصسى از اهداف اصـلى اين درمان بوده و هدف نهايى آن كمكك به بيمار مبتلا به اختلال دوقطبى براى شـكسـتن و فايق آمدن بر جر خه ى معيو ب رفتارهاى تكانه اى و بى ثباتى هيجانى است در اصل، ياد كيرى مهارتهاى تنظيم هيجان، مديريت و كنترل

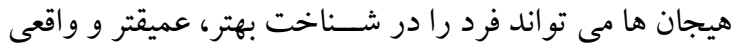
تر هيجانهاى تجربه شــده كمك كرده؛ و باعث گردد بيمار در دام رفتار هاى ناخردمندانه و بدون تفكر گرفتار نيايد. از طرفى، شناخت صرف هيجان ها نمى تواند بر ساختار كنشى و واكنشـى بيماران دوقطبى تأثير بـذارد؛ لذا شــناخت و نام كذارى هيجان ها بايد با بذيرش آنها هم جهت باشــــ جر اكه له كردن و سـر كوب هيجان ها خطرناكك بوده و قادر است سلامت روانى فرد را در طولانى مدت با مشكل مواجه سازد. از طرفى (Yr) يادگيرى، اساس و بنيان اين نوع مداخله اســـ؛ زيرا ياد گيرى برخورد مهندسـى شــده با هيجان ها و دورى از قضـاوت هاى عجولانه و خام باعث مى شـود رفتار فرد به شكل ماهر انه در آمده و رضايت كلى وى از رفتارهاى فردى و بين فردى افزايش يابد. همجنين، بر ا ساس يافته هاى 
دهى هيجانى فاكتورى بنيادين و تعيين كننده براى تجربه

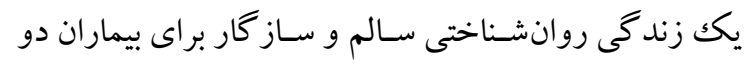

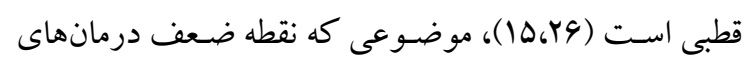
شـناختى رفتارى در جهت موفقيتهاى درمانى با اين بيماران

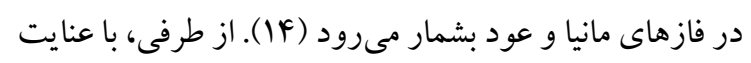
به اين امر كه در بطن مداخلهى بكار رفته، تكيهى تكاليف بيشتر بر مهارتهاى فردى استوار است؛ لذا اين امر معنى دار زشدن متغير بين فردى بنام ملامت ديخر ان را مى تواند توجيه

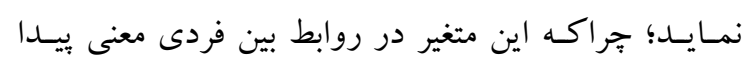

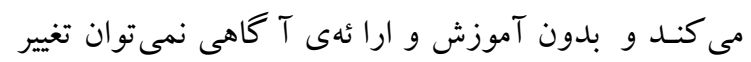

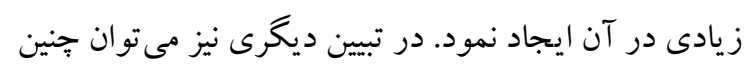
عنوان كرد كه ارتقاى ســطح عملكرد بين فردى اين بيماران

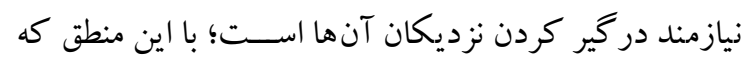

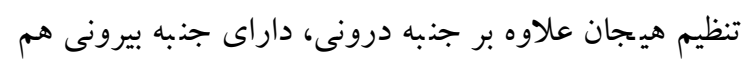

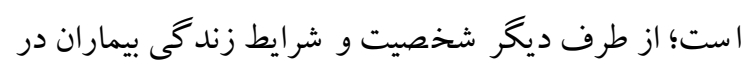
دسـت ما نيسـ؛ لذا در گير نكردن اطرافيان بيمار در جريان

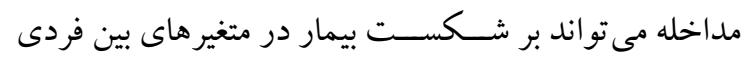

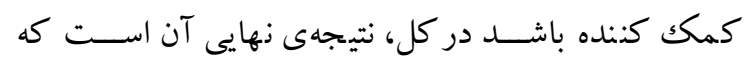

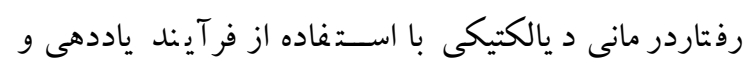

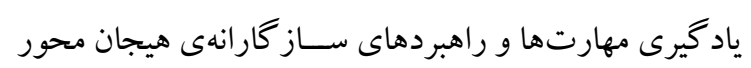

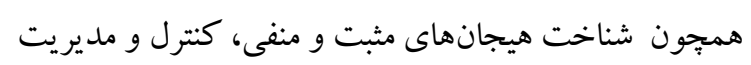

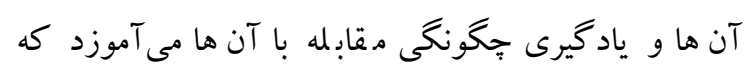

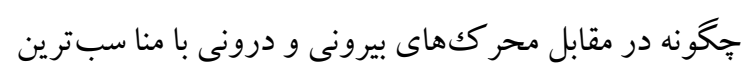

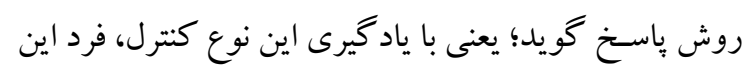

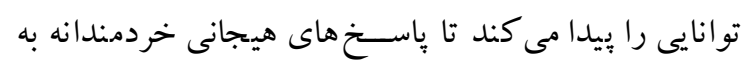

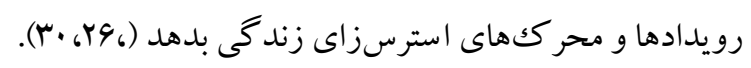

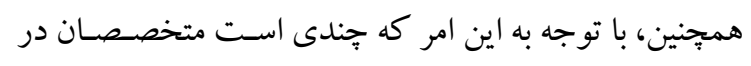

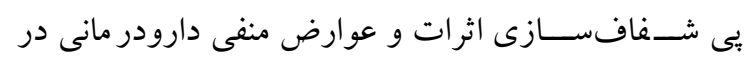

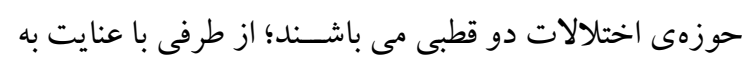

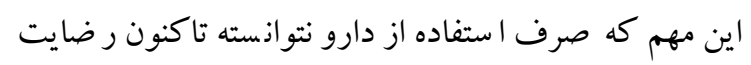

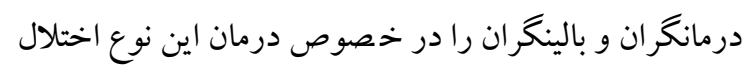

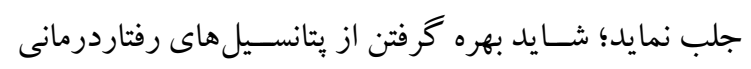

همجنين، با تو جه به فرضـيهى دوم اين يزوهش، ميانكين

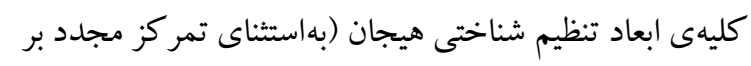

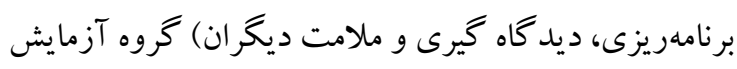

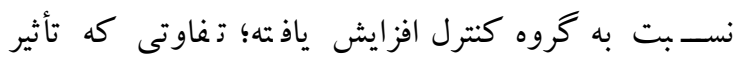

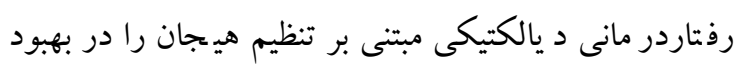

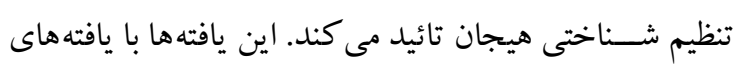

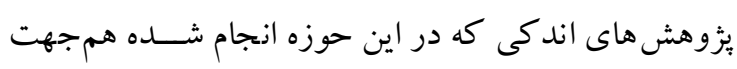

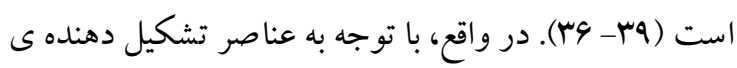

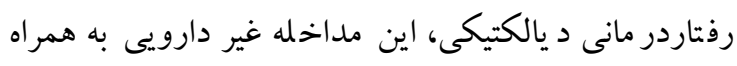

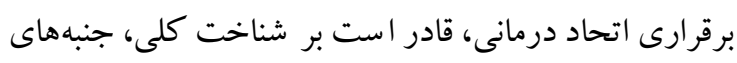

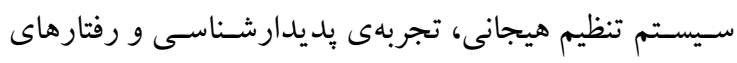

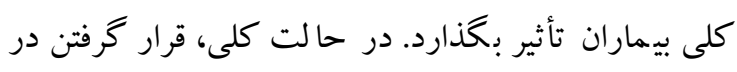

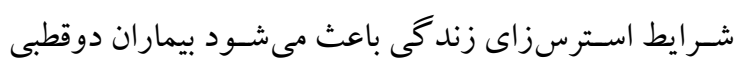
بجاى انديشيدن در خصوص بيامدهاى احتمالى رفتار متأثر از محر ككهاى درونى و بيرونى؛ واكنشى سريع و نامناسب نشان

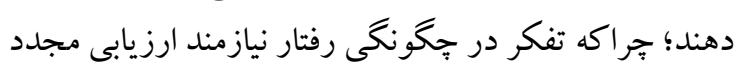
بوده و اين جريان شـناختى رفتارى از حوصسلهى اين بيماران

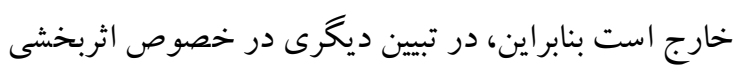

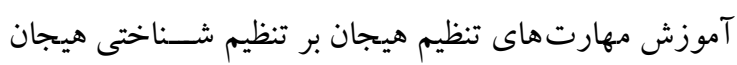

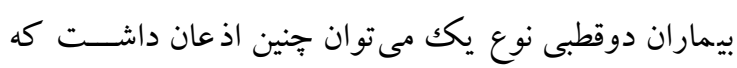

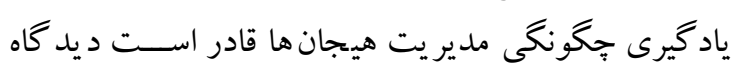
كلى فرد را در خصوص تشخيص و ارزيابى تجارب هيجانى

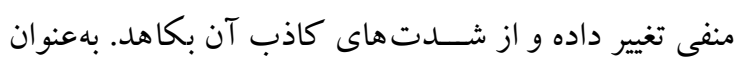

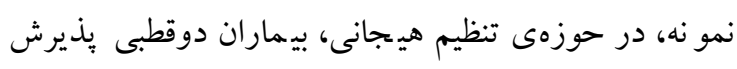

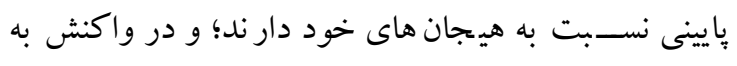
محر كك ها، حساسيت بالايى نشان مى دهند (ها). در حقيقت،

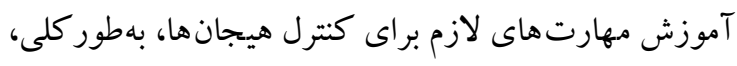

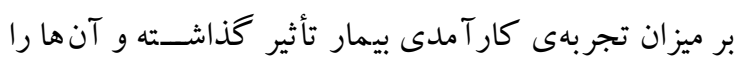
براى يذيرش و برخورد مناسب با هيجانهاى منفى مشكل ساز

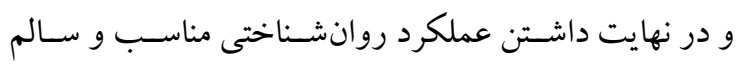

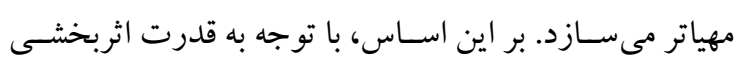

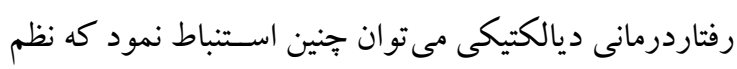


ساز كارانه ى هيجان محور همجيون شناخت هيجانهاى مثبت

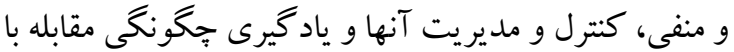

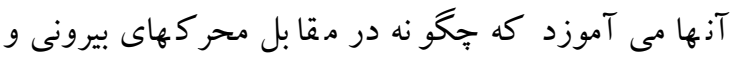

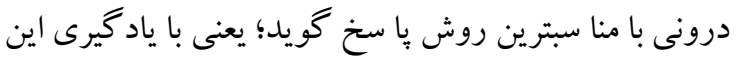

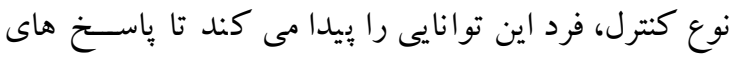
هيجانى خردمندانه به رو يدادها و محر كهاى اسـترس زاى لهاى

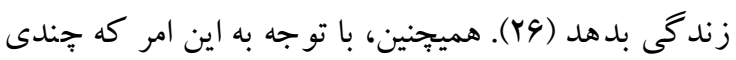
است متخصصان در يى شفاف سازى اثرات و عوارض منفى دارودرمانى در حوزه ى اختلالات دو قطبى مى باشــند؛ از طرفى با عنايت به اين مهم كه صرف استفاده از دارو نتوانسته

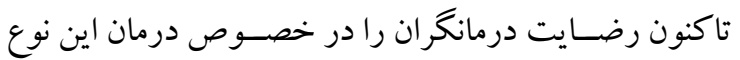
اختلال جلب نمايد؛ شــايد بهره گرفتن از يتانسـيلهاى رفتار درمانى ديالكتيكى هيجان مدار بتواند خلاء هاى درمانى اين

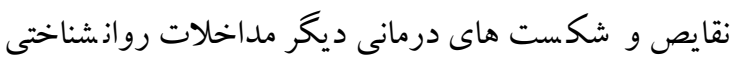

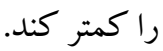

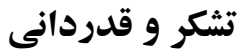

نويسند كان اين مقاله مراتب تشكر صميمانه خود را از كليهى

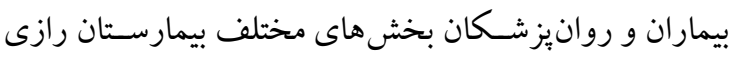
تبريز ابراز مىدار ند. همجنين، اين يُزوهش با كمكك مالى لئل

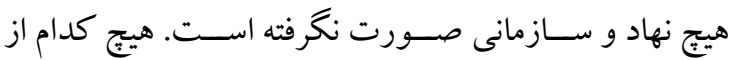

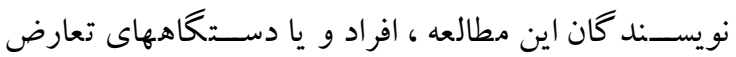
منافعى براى انتشــار اين مقاله ندارندو از هيج نهاد و فردى

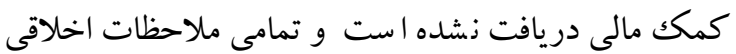

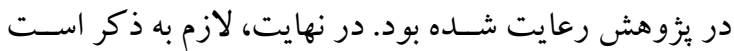
كه اين مقاله بر گرفته از رساله دكترى تخصصى روانشناسى عمومى دانشكاه آزاد اسلامى واحد تبريز است.
ديالكتيكى هيجان مدار بتو اند خلأهاى درمانى اين نقايص و شـكست هاى درمانى ديخر مداخلات روانشـناختى را كمتر

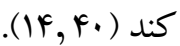
اين يزوهش با مححدوديت هايى روبه رو بود كه ذكر آنها

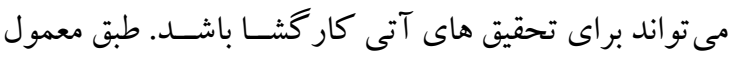

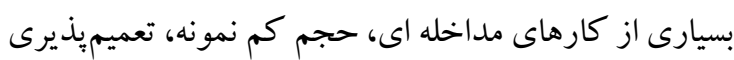

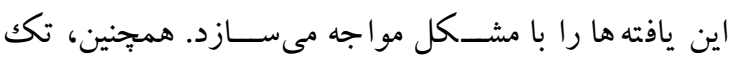
جنسيتى بودن (مردان)، عدم كنترل اثرات و عوارض داروها،

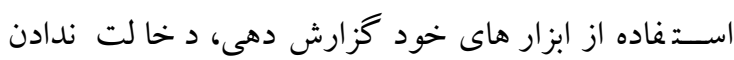

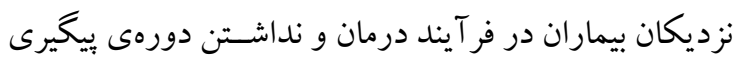
از جمله محدوديت هاى مهم اين تحقيق بشــمار مىرود. در انتها، بِيشـنهاد مىشــود: الف) از تحقيقهاى مقايسـهاى براى

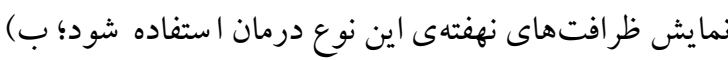

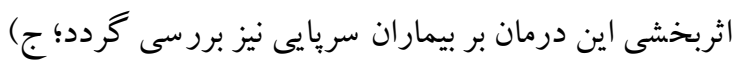

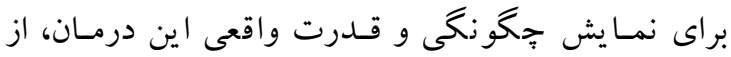
روشهاى عميقتر جمع آورى دادهها مانند مصـاحبه نيز بهره

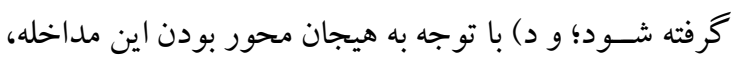

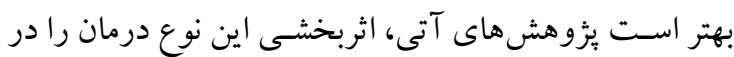

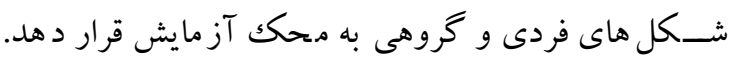
در كل، اميد است نتايج اين ثزوهش، عليرغم تمام كاستىهاى

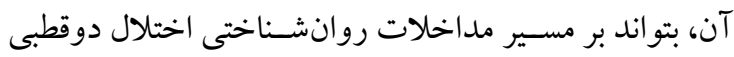

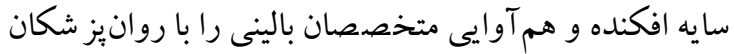

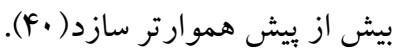

\section{نتيجه كيرى}

نتايج اين مطالعه نشـــان داد كه رفتتاردر مانى ديالكتيكى با اسـتفاده از فر آيند ياددهى و ياد گيرى مهارتها و راهبردهاى

\section{منابع}

1. Sadock BJ, Sadock VA. Comprehensive Textbook of Psychiatry. LWW. 2017; 20(11):1123-26. 
2. Green MJ, Lino B J, Hwang E-J, Sparks A, James C, Mitchell PB. Cognitive regulation of emotion in Bipolar I disorder and unaffected biological relatives. Acta Psychiatric Scandinavica. 2011; 124: 30716.

3. Van Rheenen T, Murray G, Rossell SL. Emotion regulation in bipolar disorder: Profile and utility in predicting trait mania and depression propensity. J Psyol Res. 2015; 225: 425-32.

4. Barekatain M, Khodadadi R, Maracy MR. Outcome of single manic episode in bipolar I disorder: a six-month follow-up after hospitalization. J Res Med Sci. 2011; 16(1): 56-62.

5. Miklowitz D. Family Treatment for Bipolar Disorder and Substance Abuse in Late Adolescence. J Clin Psychol. 2012; 68(5): 502-13.

6. Gago B, Perea M, Sierra P, Livianos L, Cañada-Martínez A, García-Blanco A. Do affective episodes modulate moral judgment in individuals with bipolardisorder?. J Affect Disord. 2019; 245: 289-96.

7. Reich R, Gilbert A, Clari R, Burdick KE, Szeszko PR. A preliminary investigation of impulsivity, aggression and white matter in patients with bipolar disorder and a suicide attempt history. $\mathrm{J}$ Affect Disord. 2019; 247:88-96.

8- Swann AC. Mechanisms of impulsivity in bipolar disorder and related illness. Epidemiological Psychiatric Sociale. 2011; 19(2): 120-30.

9. Swann AC, Moeller FG, Steinberg JL, Schneider L, Barratt ES, Dougherty DM. Manic symptoms and impulsivity during bipolar depressive episodes. Bip Dis. 2007; 9: 206-12.

10. Kamaldeep Bhui .Impulsivity, Attachment, and Relational Psychopathology. J Clin Psychol. 2018; 3(213): 570-76.

11. Goldstein TR, Fersch-Podrat RK, Rivera M, Axelson DA, Merranko J, Yu H, et al. Dialectical behavior therapy for adolescents with bipolar disorder: Results from a pilot randomized trial. J Child Adolesc Psycho. 2015; 25(2): 140-49.

12. Hasani J. Psychometric properties of emotional cognitive regulation questionnaire. J Clin Psychol. $2011 ; 3(7): 73-83$.

13. Javid M, Mohammadi N, Rahimi Ch. Psychometric Properties of the Persian Version of the Eleventh Barth Impact Magazine. J Psychol Meth Mod. 2012; 2(8): 23-34 (Persian).

14 .Andrada D, Neacsiu S, Jeremy W, Rachel K, Taylor W, Marsha M . Dialectical behavior therapy skills for transdiagnostic emotion dysregulation: A pilot randomized controlled trial. Beh Res and Therap. 2014; 59: 40-51.

15 . Richardson TH. Psychosocial intervention for bipolar disorder. J Med Sci. 2020; 10(6):112-143.

16. Louisa G, Rebecca E, Thilo D, Michael E, Tohen M, Melvin G, et al. Poor quality of life and functioning in bipolar disorder. Int J of Bipr Dis. 2017; 14:5-10

17.Garnefski N, Kraaij V. Relationships between cognitive emotion regulation strategies and depressive symptoms: A comparative study of five specific samples. Person and Indivi Differ. 2006; 40:1659-69.

18. Muhtadie L, Johnson S, Carver C, Gotlib H, Ketter T. A profile approach to impulsivity in bipolar disorder: The key role o strong emotions. Acta Psychiatrica Scandinavica. 2014; 129: 100-108.

19. Linehan M, Dexter-Mazze E. Dialectical Behavior Therapy for Borderline Personslity Disorder. Clin Handbook of Psych Dis. 2008; 15: 365-462.

20. Zouk H, Tousignant M, Segun M, Lesage A, Turecki G. Characterization of impulsivity in suicide completers: clinical behavioral and psychosocial dimensions. J Aff Dis. 2018; 90 (10): 195-204.

21. Akhavan Sh, Sajjadian MA. Effectiveness of Dialectical Behavior Therapy on Emotional Instability and Impulsivity in Bipolar Patients. J Clin Psychol. 2016; 3 (31): 1-15 (Persian).

22. Gholipour I, Zamani S, Jahangir S, Imani A, Zamani S. The effectiveness of impulse control and dialectical behavior therapy training on impulsivity, Lack of motor and cognitive planning inadolescent girls with disruptive mood dysregulation disorder. J Tho \& Beh in Clin Psychol. 2014;9(35): 7-16.

23.Farvareshi M, Alivandi Vafa M, Faghari A, Azmoudahe M. Effectiveness of dialectical Behavioral Therapy (Emotionregulation Skills Training) on Impulsivity and Quality of life in patients with Type I Bipolar Disorder. J Urmia Uni Medi Scs. 2019; 30(1):29-40 (Persian). 
24.Habibi M, Akbari P, Falahatpishe M, Narimani M, Abedi P. Effectiveness of Dialectical Behavior Therapy in Improving Symptoms of Patients with ysthymic Disorder. J of Hea and Care. 2016; 17(4): 329-39.

25. Zamani N, Ahmadi V, Ataie M, Mirshekar S. Comparing the Effectiveness of two Therapeutic Methods of Dialectical Behavior Therapy and Cognitive Behavior Therapy on the Improvement of Impulsive Behavior in the Patients Suffering from Major Depressive Disorder Showing a Tendency to Suicide. Sci J Ilam Uni Med Scs. 2014; 20(5):1-10(Persian).

26. Joaquim S, Carlos J, Tiana T, Cebrià A, Barrachina J, Campins M, et al .Dialectical behavior therapy skills training compared to standard group therapy in borderline personality disorder. Beh Res and Ther. 2009; 44: 128-33.

27.Telch CF, Agras WS, Linehan MM. Dialectical behavioral therapy for binge eating disorder. J Couns Psychol. 2001; 38: 1061-65.

28.Hesslinger B, Tebartz Van L, Nyberg E, Dykierek P, Richter H, Berner M, et al. Psychotherapy of attention deficit hyperactivity disorder in adults: a pilot study using a structured skills training program. Eur Arch Psychol Clin. 2002; 252: 177-84.

29. Karbalaee A, Meygoni M, Ahadi A. Declining the Rate of Major Depression: Effectiveness of Dialectical Behavior Therapy. Soc and Beh Scs. 2012; 35, 230-36 (Persian).

30. Marsha M, Linehan F. Rationale for Dialectical Behavior Therapy Skills Training. The Guilford Press [Internet]. 2015 [cited 2016 May 15]; 13: 165-72. Available from:http:// www.guilford.com/p/linehan.

31. Eisner L, Eddie D, Harley R, Jacobo M, Andrew A, Deckersbach T. Dialectical Behavior Therapy Group Skills Training for Bipolar Disorde. Beh Ther. 2017; 48 (4), 557-66.

32.Lynch TR, Chapman AL, Rosenthal MZ, Kuo JR, Linehan M. Mechanisms of change in dialectical behavior therapy: theoretical and empirical observations. J Clin Psychol. 2006; 62(4):459-80.

33. Huizen J. Finding the right medication or combination of drugs to manage bipolar disorder can be a challenging and frustrating process. Med News Today. 2019; 18:1-11.

34. Aghayousefi A, Tarkhan M, Ghorbani T. The Impact of Dialectic Behavior Therapy on the Reduction of Impulsiveness in Women with Comorbidity of Borderline Personality Disorder and Substance Abuse. Etiadpajohi. 2015; 9 (34):79-97 (Persian).

35. Lynch TR, Chapman AL, Rosenthal MZ, Kuo JR, Linehan MM. Mechanisms of change in dialectical behavior therapy: Theoretical and empirical observations. J Clin Psychol. 2006; 62(4): 45980.

36. Mozafari S, Hosseini J, Tabatabaeirad E. Dialectical Behavior Therapy and Substance Abuse Disorder: A Review of Theory and Research sh-addiction. 2017; 4 (13):111-30 (Persian).

37. Alec L, Jill H, Marsha M. Dialectical Behavior therapy with suicidal Adolescents. NewYork/London: Guilford Press. 2017: 111-20.

38. Ann M, Denise M, James J, Kelly H, Ross A. Emotion regulation and psychopathology: a transdiagnostic approach to etiology and treatment. A Division of Guilford Publication. 2010; 4: 13752.

39. Tina R, Rachael K, Maribel R, David A, John M, Haifeng Y, et al. Dialectical behavior therapy for adolescents with bipolar disorder. Result pilotr omizedtrial. J Child Adolesc Psycho Pharmacol. 2015; 25(2): 140- 9 .

40. Peluso M, HatchG J, Glahn DC, Monkul E, Sanches M, Najt P, et al. Trait impulsivity in patients with mood disorders. J Affect Dis. 2013; 6: 227-31. 